\title{
PENGARUH BREATHING EXERCISE TERHADAP LEVEL FATIGUE PASIEN HEMODIALISIS
}

\author{
Djunizar Djamaludin ${ }^{1}$, Rini Safriany², Rika Yulenda Sari ${ }^{3}$
}

${ }^{1}$ Program Studi Keperawatan Universitas Malahayati

Email: bluenavi01@gmail.com

${ }^{2}$ Rumah Sakit Umum Daerah Dr. Hi. Abdul Moeloek Provinsi Lampung

Email: safriany.rini@gmail.com

${ }^{3}$ Program Studi Keperawatan Universitas Malahayati

Email: rikangga@yahoo.com

\section{ABSTRACT: THE EFFECT OF BREATHING EXERCISE ON FATIGUE LEVELS OF HEMODIALISTIC PATIENTS}

Introduction: Fatigue is one of the problems with a high prevalence among the effects of hemodialysis on patients with late stage kidney disease. Breathing exercise is a non-pharmacological therapy to deal with various complaints such as fatigue. Abdul Moloek Hospital in Lampung Province is one of the largest referral hospitals for hemodialysis therapy for patients with chronic kidney failure. The number of kidney failure patients in 2018 is 220 patients.

Objective: the effect of Breathing Exercise on the Fatigue Level of Hemodialysis Patients in Dr. Hi Abdul Moeloek Hospital in Lampung Province in 2019.

Method: Quantitative research type, using a quasi-experimental approach. The study population was patients with kidney failure who underwent hemodialysis in February 2019 at Dr Hi Abdul Moeloek Hospital in Lampung Province as many as 300 people. The sample uses a purposive sampling of 30 respondents. Data collection techniques was done by observation. The statistical test used is the dependent $t$ test.

Results: The frequency distribution of respondents aged $\geq 50$ years was 22 (73.3\%), male sex was 19 (63.3\%) and had a junior high school education of 10 (33.3\%). The average level of fatigue of hemodialysis patients before Breathing Exercise was 37.23, after Breathing Exercise was 33.1.

Conclusion: There was the effect of breathing exercise on the level of fatigue of hemodialysis patients ( $p$ value 0,000 ). Breathingexercise is a nursing intervention that can be done to overcome weaknesses. Continuous exercise can improve health, so that the quality of life of hemodialysis patients will improve.

Keywords: Breathing Exercise, Fatigue, Hemodialysis

\section{INTISARI : PENGARUH BREATHING EXERCISE TERHADAP LEVEL FATIGUE PASIEN HEMODIALISIS}

Pendahuluan: Fatigue atau kelelahan adalah salah satu masalah dengan prevalensi yang cukup tinggi diantara efek tindakan hemodialisis yang diterima pasien dengan penyakit ginjal tahap akhir. Breathing exercise adalah terapi nonfarmakologi untuk mengatasi berbagai keluhan seperti fatigue. RSUD Abdul Moloek provinsi lampung merupakan salah satu rumah sakit rujukan terbesar untuk melakukan terapi hemodialisis bagi pasien gagal ginjal kronis. Jumlah pasien gagal ginjal tahun 2018 sebanyak 220 pasien. 
Tujuan: diketahui pengaruh Breathing Exercise Terhadap Level Fatigue Pasien Hemodialisis Di RSUD Dr Hi Abdul Moeloek Provinsi Lampung Tahun 2019.

Metode: Jenis penelitian kuantitatif, menggunakan pendekatan quasi eksperimen. Populasi penelitian adalah penderita gagal ginjal yang menjalani hemodialisa pada bulan Februari 2019 sejumlah 300 orang. Sampel menggunkan purposive sampling sejumlah 30 responden. Tehnik pengumpulan data dilakukan dengan observasi. Uji statistik yang digunakan adalah uji $t$ dependen.

Hasil: distribusi frekuensi responden berusia $\geq 50$ tahun $(73,3 \%)$, berjenis kelamin laki-laki $(63,3 \%)$ dan berpendidikan akhir SMP (33,3\%). Rata-rata Level Fatigue sebelum diberikan Breathing Exercise adalah 37.23. Sesudah diberikan Breathing Exercise adalah 33.1.

Kesimpulan: Ada pengaruh breathing exercise terhadap level fatigue pasien hemodialisis ( $p$ value 0,000). Breathingexercise merupakan intervensi keperawatan yang dapat dilakukan untuk mengatasi kelemahan. Latihan yang kontinyu dapat meningkatkan kesehatan, sehingga kualitas hidup pasien hemodialisis akan meningkat.

Kata Kunci : Breathing Exercise, Fatigue, Hemodialisis

\section{PENDAHULUAN}

Penyakit ginjal kronik atau chronic kidney disease (CKD) adalah proses patofisiologi dengan etiologi yang beragam, dimana ginjal mengalami penurunan fungsi secara lambat, progresif, dan irreversibel dimana kemampuan tubuh gagal dalam mempertahankan metabolism dan keseimbangan cairan dan elektrolit sehingga menyebabkan terjadinya uremia atau azotemia. Pada penyakit ginjal tahap akhir terapi pengganti ginjal diperlukan untuk memperpanjang hidup. Terapi pengganti ginjal dapat berupa hemodialisis dan transplantasi ginjal yang gunanya tidak hanya untuk memperpanjang hidup akan tetapi juga untuk mengembalikan kualitas hidup dengan meningkatkan kemandirian pasien (Smeltzer \& Bare, 2015).

Berdasarkan estimasi Badan Kesehatan Dunia WHO (2017) secara global lebih dari 500 juta orang mengalami penyakit gagal ginjal kronik. Sekitar 1,5 juta orang harus menjalani hidup bergantung pada hemodialisis. Di Amerika Serikat setiap tahun selalu mengalami peningkatan 2,1 \% dan pada tahun
2011 lebih dari 380.000 orang penderita penyakit ginjal kronis menjalani hemodialisis regular (USRDS, 2016). Sedangkan di Indonesia berdasarkan data dari Riskesdas (2018) pada tahun 2018 tercatat sebesar 3,8 per 1.000 penduduk menderita GGK angka tersebut lebih tinggi jika dibandingkan tahun 2013 yaitu sebesar 2,2 per 1.000 penduduk, dengan jumlah penduduk yang menjalani hemodialisa mencapai $19,3 \%$.

Meskipun pasien yang menerima dialisis sekarang hidup lebih lama, kebanyakan dari mereka mengalami gejala yang mengganggu kemampuan mereka untuk berfungsi sesuai dengan kapasitas normal mereka dan menghambat kualitas. Proses terapi hemodialisis yang membutuhkan waktu 5 jam, umumnya akan menimbulkan stress fisik pada pasien setelah hemodialisis. Belum lagi permasalahan yang timbul selama proses hemodialisis berlangsung seperti intradialytic hypotension, kram otot, sakit kepala, mual, hipertensi, disequilibrium syndrome dan sebagainya. Pasien akan merasakan kelelahan dan keluar keringat dingin akibat tekanan darah 
yang menurun sehubungan dengan efek hemodialisis (Hilma, 2015).

Fatigue atau kelelahan adalah salah satu masalah dengan prevalensi yang cukup tinggi diantara efek tindakan hemodialisis yang diterima pasien dengan penyakit ginjal tahap akhir. Beberapa penelitian menunjukkan bahwa $71,0 \%$ sampai 92,2\% pengalaman pasien dengan kelelahan dan bahwa kelelahan adalah kondisi yang paling penting untuk diobservasi pada pasien dengan penyakit ginjal kronik (Rabiye, et al., 2015; Hilma, 2015). Pada pasien yang menjalani hemodialisa dalam waktu lama, simptom fatigue dialami $82 \%$ sampai 90\% pasien (Kring \& Crane, 2009).

Kondisi kelelahan pada pasien hemodialisis dapat menyebabkan konsentrasi menurun, malaise, gangguan tidur, gangguan emosional dan penurunan kemampuan pasien dalam melakukan aktifitas sehariharinya, sehingga pada akhirnya dapat menurunkan kualitas hidup pasien hemodialisis (Jhamb, 2015). Terdapat beberapa kondisi yang dapat mempengaruhi kelelahan pada pasien hemodialisis yaitu uremia, anemia, malnutrisi, depresi, dan kurangnya aktifitas fisik. Uremia pada pasien hemodialisis dapat menyebabkan pasien kehilangan nafsu makan, mual, muntah, kehilangan energi dan protein, dan penurunan produksi kreatinin yang menyebabkan penurunan produksi energi untuk skeletal dan mengakibatkan fatigue atau kelelahan (Jhamb, 2008 ; Brunner \& Suddarth, 2015).

Metode penanganan terhadap kelelahan atau fatigue dilakukan kedalam dua cara yaitu farmakologi dan nonfarmakologi. Metode penambahan $L$-carnitine, vitamin $\mathrm{C}$ dan eritropoetin dan pengobatan untuk mengontrol anemia. Metode terakhir yang dikembangkan adalah exercise, yoga, relaksasi, akupresur, akupunktur, stimulasi elektrik, dan dialysis. Exercise mungkin membantu dalam mengurangi depresi dan kelelahan diantara pasien hemodialisis. Namun beberapa studi menyarankan bahwa teknik relaksasi dianggap berhasil dalam meningkatkan kondisi pasien hemodialisis (Hilma, 2015).

Breathing exercise adalah terapi nonfarmakologi yaitu teknik penyembuhan yang alami dan merupakan bagian dari strategi holistic self-care untuk mengatasi berbagai keluhan seperti fatigue, nyeri, gangguan tidur, stress dan kecemasan. Secara fisiologis, breathing exercise akan menstimulasi sistem saraf parasimpatik sehingga meningkatkan produksi endorpin, menurunkan heart rate, meningkatkan ekspansi paru sehingga dapat berkembang maksimal, dan otot- otot menjadi rileks. Breathing exercise membuat tubuh kita mendapatkan input oksigen yang adekuat. dimana oksigen memegang peran penting dalam sistem respirasi dan sirkulasi tubuh. Saat kita melakukan breathing exercise, oksigen mengalir ke dalam pembuluh darah dan seluruh jaringan tubuh, membuang racun dan sisa metabolisme yang tidak terpakai, meningkatkan metabolisme dan memproduksi energi. Breathing exercise akan memaksimalkan jumlah oksigen yang masuk dan disuplay ke seluruh jaringan sehingga tubuh dapat memproduksi energi dan menurunkan level fatigue (Septiwi, 2016).

RSUD Abdul Moeloek provinsi lampung merupakan salah satu rumah sakit rujukan terbesar untuk melakukan terapi hemodialisis bagi pasien gagal ginjal kronis. Dalam tiga tahun berturut turut pasien gagal ginjal di RSUD Abdul Moeloek provinsi lampung mengalami peningkatan yaitu tahun 2016 sebanyak 160 pasien , tahun 2017 sebanyak 195 pasien dan tahun 2018 sebanyak 220 pasien (Ruang Hemodialisis Abdul 
Moeloek provinsi lampung, 2018).

Berdasarkan survei awal yang

dilakukan terhadap pasien yang menjalani hemodialisis didapatkan hasil bahwa hampir semua pasien mengalami kelelahan sepanjang hari dan umumnya mereka tidak tahu cara untuk mengatasinya walaupun telah mengkonsumsi obat dari dokter. Dari 15 orang pasien yang ditanya didapatkan hasil bahwa 8 orang pasien $(53,3 \%)$ mengatakan tidak dapat melakukan tindakan perawatan diri tergantung pada anggota keluarga, 2 orang $(13,3 \%)$ mengatakan nafas sering sesak dan merasa lelah bila beraktifitas, 2 orang $(13,3 \%)$ mengatakan membatasi aktifitas supaya tidak lelah, 2 orang $(13,3 \%)$ mengatakan dapat beraktifitas tapi tidak seperti semula sebelum sakit.

\section{METODE PENELITIAN}

Dalam penelitian ini mengunakan jenis penelitian kuantitatif. Penelitian dilakukan di Ruang Hemodialisa RSUD $\mathrm{Dr} \mathrm{Hi}$ Abdul Moeloek Provinsi Lampung. Penelitian ini dilaksanakan pada tanggal $18 \mathrm{Mei}$ 18 Juni 2019. Dalam penelitian ini peniliti menggunakan rancangan analisis dengan quasi eksperimen. Populasi dalam penelitian ini adalah penderita gagal ginjal yang menjalani hemodialisa pada bulan Februari 2019 di RSUD Dr Hi Abdul Moeloek Provinsi Lampung sejumlah 300 orang. Sehingga jumlah keseluruhan responden sebanyak $10 \%$ dari sampel 30 orang. Teknik sampling purposive sampling. Variabel independen Breathing Exercise, variabel dependen Level Fatigue. Pengukuran Fatique dengan menggunakan Fatigue Severity Scale. Kuesioner terdiri dari sembilan HASIL

\section{Karakteristik Responden}

Kebanyakan dari pasien hemodialisis menghabiskan waktunya di rumah bahkan kurang juga melakukan sosialisasi dengan lingkungan sosialnya dengan alasan merasa malas dan letih. Pasien sering mengeluhkan kelelahan yang mereka alami kepada perawat dan dokter namun hanya terapi medikasi yang selama ini diberikan, tapi pasien tetap saja masih merasakan kelelahan mereka, sehingga belum nampak di sini peran perawat sebagai pemberi asuhan.

Berdasarkan fenomena di atas peneliti tertarik untuk melakukan penelitian Pengaruh Breathing Exercise Terhadap Level Fatigue Pasien Hemodialisis Di RSUD $\mathrm{Dr} \mathrm{Hi}$ Abdul Moeloek Provinsi Lampung Tahun 2019.

pernyataan. Penilaian dilakukan untuk melihat efek kelelahan terhadap motivasi, aktivitas, fungsi fisik, menjalankan tugas, gangguan terhadap pekerjaan, keluarga, ataupun kehidupan sosial. Skala yang digunakan adalah skala Likert dengan skala 1 (sangat tidak setuju) hingga 7 (sangat setuju). Intepretasi hasil menandakan makin tinggi skor, makin tinggi derajat keparahan dari kelelahan yang dirasakan. Analisa univariat dilakukan dengan analisis distribusi frekuensi dan hasil statistik deskriptif dari variabel yang diteliti meliputi mean, median, standart deviasi, nilai minimal dan maksimal. Analisa bivariat dilakukan untuk melihat pengaruh Breathing Exercise Terhadap Level Fatigue Pasien Hemodialisis, analisis bivariat dilakukan dengan cara: Uji $t$ dependen.

Tabel 1.

Distribusi usia, jenis kelamin, lama menjalani HD pada pasien hemodialisis 


\begin{tabular}{|c|c|c|}
\hline Karakteristik & Frekuensi & $\%$ \\
\hline \multicolumn{3}{|l|}{ Umur: } \\
\hline$-\quad<50$ Tahun & 8 & 26.7 \\
\hline - $\quad \geq 50$ Tahun & 22 & 73.3 \\
\hline \multicolumn{3}{|l|}{ Jenis kelamin: } \\
\hline - Laki-laki & 19 & 63.3 \\
\hline - Perempuan & 11 & 36.7 \\
\hline \multicolumn{3}{|l|}{ Pendidikan: } \\
\hline$-\quad S D$ & 8 & 20.0 \\
\hline - SMP & 10 & 33.3 \\
\hline - SMA & 6 & 20.0 \\
\hline - $\quad$ PT & 8 & 26.7 \\
\hline Jumlah & 30 & 100.0 \\
\hline
\end{tabular}

Tabel diatas menunjukkan sebagian besar responden berusia $\geq 50$ tahun yaitu sebanyak 22 responden $(73,3 \%)$, berjenis kelamin laki-laki sebanyak 19 responden $(63,3 \%)$ dan berpendidikan akhir SMP sebanyak 10 responden $(33,3 \%)$.

\section{Analisis Univariat}

Pada bagian ini akan dijelaskan Level Fatigue pasien hemodialisis sebelum dan sesudah diberikan Breathing Exercise.

a. Level Fatigue pasien hemodialisis sebelum diberikan Breathing Exercise

Tabel 2.

Rata-Rata Level Fatigue pasien hemodialisis sebelum diberikan Breathing

Exercise

\begin{tabular}{lccc} 
& \multicolumn{1}{c}{$\mathrm{n}=30$} \\
\hline \multicolumn{1}{c}{ Level Fatigue } & Mean & SD & Min-Mak \\
\hline $\begin{array}{l}\text { Sebelum Breathing } \\
\text { Exercise }\end{array}$ & 37.23 & 8.69 & $20-59$ \\
\hline
\end{tabular}

Hasil analisis didapatkan rata-rata Level Fatigue pasien hemodialisis sebelum diberikan Breathing Exercise adalah 37.23 dengan SD 8,69. Level Fatigue terendah adalah 20 dan yang tertinggi adalah 59. Hasil estimasi interval dapat disimpulkan bahwa 95\% diyakini bahwa rata-rata Level Fatigue pasien hemodialisis sebelum diberikan Breathing Exercise adalah antara 33,9-40,5.

b. Level Fatigue pasien hemodialisis sesudah diberikan Breathing Exercise

Tabel 3.

Rata-Rata Level Fatigue pasien hemodialisis sesudah diberikan Breathing 


\begin{tabular}{lccc}
\multicolumn{3}{c}{ Exercise } & $\mathrm{n}=30$ \\
\hline \multicolumn{1}{c}{ Level Fatigue } & Mean & SD & Min-Mak \\
\hline $\begin{array}{l}\text { Sesudah Breathing } \\
\text { Exercise }\end{array}$ & 33,1 & 8,6 & $18-55$ \\
\hline
\end{tabular}

Hasil analisis didapatkan rata-rata Level Fatigue pasien hemodialisis sesudah diberikan Breathing Exercise adalah 33.1 dengan SD 8,6. Level Fatigue terendah adalah 18 dan yang tertinggi adalah 55. Hasil estimasi interval dapat disimpulkan bahwa 95\% diyakini bahwa rata-rata Level Fatigue pasien hemodialisis sesudah diberikan Breathing Exercise adalah antara 29,8-36,3.

\section{Uji Normalitas}

Tabel 4.

Hasil Uji Normalitas

\begin{tabular}{lcc}
\hline \multicolumn{1}{c}{ Variabel } & Sig & Keterangan \\
\hline $\begin{array}{l}\text { Level Fatigue sebelum } \\
\text { diberikan Breathing Exercise }\end{array}$ & 0,2 & Normal \\
\hline $\begin{array}{l}\text { Level Fatigue sesudah } \\
\text { diberikan Breathing Exercise }\end{array}$ & 0,2 & Normal \\
\hline
\end{tabular}

Tabel diatas menunjukan bahwa uji normalitas nilai Sig. Uji Kolmogorov-
Smirnov > 0,05, maka semua data berdistribusi normal.

\section{Analisis Bivariat}

Tabel 5.

Pengaruh Breathing Exercise Terhadap Level Fatigue Pasien Hemodialisis

\begin{tabular}{lccccc}
\hline \multicolumn{1}{c}{ Level Fatigue } & Mean \pm SD & SE & $t$ & $\rho$ Value & $96 \% \mathrm{Cl}$ \\
\hline Sebelum & $37.23 \pm 8.69$ & 1.58 & 22,45 & 0,000 & $3,76-4,5$ \\
Sesudah & $33.1 \pm 8.61$ & 1.57 & & & \\
\hline
\end{tabular}

Hasil penelitian didapatkan bahwa rata-rata Level Fatigue pasien hemodialisis sebelum diberikan Breathing Exercise adalah 37.23 dengan SD 8,69. Sedangkan rata-rata Level Fatigue pasien hemodialisis sesudah diberikan Breathing Exercise adalah 33.1 dengan SD 8,6 sehingga dapat disimpulkan bahwa ada perbedaan rata-rata Level Fatigue PEMBAHASAN

\section{Level Fatigue pasien hemodialisis sebelum diberikan Breathing Exercise}

pasien hemodialisis sebelum dengan sesudah diberikan Breathing Exercise. Hasil uji statistik didapatkan nilai $\rho=$ 0,000 ( $p$ hitung $<\alpha$ ), artinya pada $\alpha=$ $5 \%$ dapat diartikan ada pengaruh breathing exercise terhadap level fatigue pasien hemodialisis di RSUD Dr $\mathrm{Hi}$ Abdul Moeloek Provinsi Lampung Tahun 2019.

Hasil analisis didapatkan rata-rata Level Fatigue pasien hemodialisis sebelum diberikan Breathing Exercise adalah 37.23 dengan SD 8,69. Level 
Fatigue terendah adalah 20 dan yang tertinggi adalah 59.

Fatigue muncul sebagai akibat dari berbagai faktor diantaranya adalah faktor fisiologis (anemia, malnutrisi, uremia, hyperparathyroid, inflamasi) yang dimunculkan dari proses penyakit gagal ginjal kronis. Faktor psikologis diantaranya stres, depresi, ansietas dapat memicu terjadinya fatigue. Respon stres masuk ke dalam sistem saraf pusat, lalu di hipothalamus dilepaskan corticotrophin hormone releasing factor yang akan menstimulasi sistem saraf simpatis untuk mengeluarkan norepinefrin yang merupakan vasokonstriktor dan berakibat pada kontraksi otot polos (Valentino dan Bockstaele, 2008).

Hal ini sesuai dengan penelitian Penelitian Septiwi (2013) tentang Pengaruh Breathing Exercise Terhadap Level Fatigue Pasien Hemodialisis Di RSPAD Gatot Subroto Jakarta, rata-rata level fatigue responden sebelum dilakukan breathing exercise adalah 5,70, level fatigue 4 , sedangkan 3 responden (30\%) berada pada level5, 4 responden (40\%) berada pada level 6, dan 2 responden $(20 \%)$.

Keluhan fatigue pada pasien hemodialisis prevalensinya mencapai 60-97\% dan merupakan salah satu efek dari terapi dialisis yang harus dijalani oleh pasien penyakit ginjal terminal. Responden dalam penelitian ini mengalami fatigue dengan level yang bervariasi, yang disebabkan oleh kondisi uremia dengan kadar ureum di atas normal, anemia dengan $\mathrm{Hb}$ ratarata $9 \mathrm{~g} / \mathrm{dL}$, dan kurang intake nutrisi karena adanya mual dan muntah akibat uremia.

Fatigue yang dialami oleh responden menyebabkan penurunan konsentrasi, malaise, gangguan tidur, gangguan emosional, dan penurunan kemampuan pasien dalam melakukan aktivitas sehari-harinya.

\section{Level fatigue setelah breathing exercise}

Hasil analisis didapatkan ratarata Level Fatigue pasien hemodialisis sesudah diberikan Breathing Exercise adalah 33.1 dengan SD 8,6. Level Fatigue terendah adalah 18 dan yang tertinggi adalah 55. Hasil estimasi interval dapat disimpulkan bahwa 95\% diyakini bahwa rata-rata Level Fatigue pasien hemodialisis sesudah diberikan Breathing Exercise adalah antara 29,8-36,3.

Breathing exercise merupakan latihan pernapasan dengan tehnik bernapas secara perlahan dan dalam, menggunakan otot diafragma, sehingga memungkinkan abdomen terangkat perlahan dan dada mengembang penuh (Smeltzer, et al, 2013). Nafas dalam adalah suatu tindakan keperawatan dimana perawat akan mengajarkan/melatih klien agar mampu dan mau melakukan nafas dalam secara efektif sehingga kapasitas vital dan ventilasi paru meningkat (Rosyidi, 2013).

Hal ini sesuai dengan penelitian Penelitian Septiwi (2013) tentang Pengaruh Breathing Exercise Terhadap Level Fatigue Pasien Hemodialisis Di RSPAD Gatot Subroto Jakarta, yang menunjukkan 1 responden $(10 \%)$ yang mempunyai level fatigue 2 , sedangkan 4 responden (40\%) berada pada level 3 , 2 responden $(20 \%)$ berada pada level 4, 2 responden (20\%) berada pada level 5, dan 1 responden (10\%) berada pada level 6.

Menurut peneliti penerapan intervensi breathing exercise pada 10 responden berdampak positif setelah dilakukan secara teratur selama 4 minggu, ditunjukkan dari penurunan level fatigue pada semua responden dengan tingkat yang bervariasi. Perbedaan penurunan level fatigue disebabkan oleh kondisi, frekuensi dan ketekunan responden dalam melakukan latihan ini di rumah, 
karena latihan ini tidak hanya dilakukan selama proses hemodialisis saja.

\section{Pengaruh Breathing Exercise Terhadap Level Fatigue Pasien Hemodialisis \\ Berdasarkan hasil penelitian} diketahui bahwa rata-rata Level Fatigue pasien hemodialisis sebelum diberikan Breathing Exercise adalah 37.23 dengan SD 8,69. Sedangkan rata-rata Level Fatigue pasien hemodialisis sesudah diberikan Breathing Exercise adalah 33.1 dengan SD 8,6 sehingga dapat disimpulkan bahwa ada perbedaan rata-rata Level Fatigue pasien hemodialisis sebelum dengan sesudah diberikan Breathing Exercise. Hasil uji statistik didapatkan nilai $\rho=0,000$ ( $p$ hitung $<\alpha$ ), artinya pada $\alpha=5 \%$ dapat diartikan ada pengaruh breathing exercise terhadap level fatigue pasien hemodialisis di RSUD $\mathrm{Dr} \mathrm{Hi}$ Abdul Moeloek Provinsi Lampung Tahun 2019.

Hal ini sesuai dengan penelitian Penelitian Septiwi (2013) tentang Pengaruh Breathing Exercise Terhadap Level Fatigue Pasien Hemodialisis Di RSPAD Gatot Subroto Jakarta, rata-rata level fatigue responden sebelum dilakukan breathing exercise adalah 5,70, sesudah breathing exercise adalah 3,80 , dan perbedaan nilai mean adalah 1,90. Hasil uji $T$ berpasangan (paired $t$ test) didapatkan nilai $p$ $0,000(p<0,05)$ sehingga dapat disimpulkan bahwa terdapat perbedaan yang signifikan antara level fatigue sebelum dan sesudah breathing exercise. Penelitian Astuti (2016) tentang Napas Dalam Menurunkan Tingkat Kelelahan Pasien Post Hemodialisis Di Ruang Hemodialisis Rumah Sakit, menunjukkan tingkat kelelahan pada pasien post hemodialisis sebelum dilakukan napas dalam yaitu 16 responden $(61,5 \%)$. Tingkat kelelahan pada pasien post hemodialisis sesudah dilakukan napas yaitu 6 responden $(23,1 \%)$. Terdapat pengaruh antara napas dalam terhadap tingkat kelelahan pada pasien post hemodialisis dengan nilai $\mathrm{p}$ sebesar 0,002 dan secara klinis terdapat perbedaan sebesar $38,4 \%$.

Napas dalam merupakan intervensi non farmakologi berupa suatu teknik pernapasan yang dapat dilakukan secara mandiri untuk meningkatkan ventilasi paru dan meningkatkan perfusi oksigen ke jaringan perifer. Pada umumnya pasien hemodialisis mengalami tingkat kelelahan dikarenakan terganggunya homeostasis tubuh akibat akumulasi limbah produk metabolisme. Hemodialisis merupakan terapi wajib yang harus dilakukan secara rutin untuk mengekskresikan akumulasi limbah tersebut. Hasil penelitian ini menunjukkan bahwa perbedaan bermakna mengenai tingkat kelelahan pasien antara sebelum dan sesudah nafas dalam. Hal tersebut sesuai dengan konsep teori yang menyatakan bahwa napas dalam merupakan salah satu teknik pernapasan secara mandiri untuk meningkatkan ventilasi paru dan meningkatkan perfusi oksigen ke jaringan perifer dan merupakan salah satu bentuk terapi yang mampu meringankan gejala kelelahan (Black \& Hawks, 2014). Selain itu, napas dalam juga dapat dilakukan kapan dan dimana saja tidak harus dalam pengawasan tenaga medis mengingat napas dalam tidak memiliki efek samping yang berbahaya.

Menurut peneliti Breathing exercise merupakan teknik penyembuhan yang alami dan merupakan bagian dari strategi holistic self-care untuk mengatasi berbagai keluhan seperti fatigue, nyeri, gangguan tidur, stress dan kecemasan. Secara fisiologis, breathing exercise akan menstimulasi sistem saraf parasimpatik sehingga 
meningkatkan produksi endorpin, menurunkan heart rate, meningkatkan ekspansi paru sehingga dapat berkembang maksimal, dan otot-otot menjadi rileks. Breathing exercise membuat tubuh kita mendapatkan input oksigen yang adekuat, dimana oksigen memegang peran penting dalam sistem respirasi dan sirkulasi tubuh. Saat kita melakukan breathing exercise, oksigen mengalir ke dalam pembuluh darah dan seluruh jaringan tubuh, membuang racun dan sisa metabolisme yang tidak terpakai, meningkatkan metabolisme dan memproduksi energi. Breathing exercise akan memaksimalkan jumlah oksigen yang masuk dan disuplay ke seluruh jaringan sehingga tubuh dapat memproduksi energi dan menurunkan level fatigue.

\section{Keterbatasan penelitian}

Jumlah responden yang digunakan hanya memenuhi minimal jumlah sampel karena hambatan memperoleh lebih banyak jumlah responden yang sesuai dengan kriteria.

\section{Kesimpulan}

1. Distribusi frekuensi responden berusia $\geq 50$ tahun yaitu sebanyak 22 responden $(73,3 \%)$, berjenis kelamin lakilaki sebanyak 19 responden $(63,3 \%)$ dan berpendidikan akhir SMP sebanyak 10 responden $(33,3 \%)$.

2. Rata-rata Level Fatigue pasien hemodialisis sebelum diberikan Breathing Exercise adalah 37.23 dengan SD 8,69.

3. Rata-rata Level Fatigue pasien hemodialisis sesudah diberikan Breathing Exercise adalah 33.1 dengan SD 8,6

4. Ada pengaruh breathing exercise terhadap level fatigue pasien hemodialisis di RSUD $\mathrm{Dr} \mathrm{Hi}$ Abdul Moeloek
Provinsi Lampung Tahun 2019

( $p$ value 0,000 )

\section{Saran}

1. Bagi Ruang Hemodialisa

Agar menerapkan Breathing

exercise di ruang hemodialisis karena mudah dipelajari, dapat dilakukan oleh siapa saja dan kapan saja, tidak memerlukan alat dan tempat yang khusus, tidak membahayakan, akan tetapi memerlukan ketelatenan dan kesabaran karena latihan ini akan efektif bila dilakukan secara kontinyu.

2. Bagi Pasien HD

Agar melakukan Breathing exercise untuk mengatasi kelemahan. Latihan yang kontinyu dapat meningkatkan kesehatan, sehingga kualitas hidup pasien hemodialisis akan meningkat

\section{DAFTAR PUSTAKA}

Astuti. (2016). Napas Dalam Menurunkan Tingkat Kelelahan Pasien Post Hemodialisis Di Ruang Hemodialisis Rumah Sakit

Black, J. M., \& Hawks, J. H. (2014). Keperawatan medikal bedah: manajemen klinis untuk hasil yang diharapkan. Elsevier (Singapore).

Brunner, L. S., \& Suddarth, D. S. (2015). Medical surgical nursing (Vol. 2123). Philadelphia: Lippincott Williams \& Wilkins.

Buratburat (2014) Uji Reliabilitas Dan Validitas Fatigue Severity Scaleversi Bahasa Indonesiapada Dokter Residen RSUP DR. Sardjito Yogyakarta

Hilma. (2015). Pengaruh Teknik Relaksasi Nafas Dalam Terhadap Penurunan Kelelahan Pasien Gagal Ginjal Kronik Yang Menjalani Hemodialisis Di Unit Hemodialisis RSUP Dr. M. 
Djamil Padang. Fakultas Keperawatan.

Jhamb. (2008). Fatigue in patientsreceiving maintenance dialysis: a review of definitions, measures, and contributing factors. American Journal of Kidney Disease, 52(2), 353-365

Kemenkes RI. 2018. Riset Kesehatan

Pertiwi (2013) Pengaruh Breathing Exercise Terhadap Level Fatigue Pasien Hemodialisis Di RSPAD Gatot Subroto Jakarta

Rosyidi, Kholid. 2013. Prosedur Praktik Keperawatan Jilid 1. Trans Info Media: Jakarta

Septiwi (2013). Pengaruh Breathing Exercise Terhadap Level Fatigue Pasien Hemodialisis Di RSPAD Gatot Subroto Jakarta. https: //ejournal.stikesmuhgo mbong.ac.id/index.php/JIKK/ article/view/117

Smeltzer, S.C. \& Bare, B.G. (2013). Buku Ajar Keperawatan
Medikal Bedah Brunner \& Suddarth, edisi 8. Jakarta : EGC

USRDS. United States Renal Data System (USRDS) [Internet]. USRDS. 2016 Eustace JA, Coresh J. Chronic Kidney Disease, Dyalisis, and Transplantation: Elseiver. Tahun 2009.

Valentino, R. J., \& Van Bockstaele, E. (2008). Convergent regulation of locus coeruleus activity as an adaptive response to stress. European journal of pharmacology, 583(2-3), 194203. 